\title{
Squash plants between classic and modern genetics
}

\section{Opinion}

\section{Why I use squash?}

Squash fruits are used for local consumption and for export. Squash fruits contain some nutritional compounds for human feeding such as moderate quantity of mineral salts, it is eaten cocked as an immature fruit which is rich with fibers and vitamins or consumed for the mature seed which is a good source of fats and protein. Summer squash has twenty pairs of chromosomes and has a wide range of variability in shape and color. It is an interesting plant for genetically studies. Many of the genetic variations that have arisen were perpetuated for their horticultural values and rich reservoir of genetic diversity.

\section{Produce new hybrids of squash}

My currently work about the breeding of the family Cucurbitaceae it is one of the most important botanical families for human including favorable and common vegetable crops. Cucurbits including squash have been cultivated over centuries. Summer squash are the edible immature fruits of Cucurbita pepo L., a highly diverse species of the gourd family, Cucurbitaceae. Summer squash are an easy-to-grow, short-season crop best adapted to temperate and subtropical regions. Squash is considered to be one of the most popular vegetable crops grown in Egypt. It is known as a vegetable marrow and is called also "Kosa" by the Egyptian people. In Egypt, Squash is usually grown all over the year specially in summer season and small area in the nili season. In the same time, there are few number of the superior F1 hybrids grown in green houses and others for the open fields.

I hope to produce a large numbers of squash hybrids have hybrid vigor by use complete diallel mating design because I use the parental Varity of squash once female in F1 hybrid and once male in the F1r reciprocal hybrid to estimate the maternal effects. At the first, in my M.Sc. study I produce 12 hybrids (6 F1 hybrids and $6 \mathrm{~F} 1 \mathrm{r}$ reciprocal hybrids). In this method in my Ph.D. studied I use seven parental Varity of squash to produce 42 hybrids ( $21 \mathrm{~F} 1$ hybrids and $21 \mathrm{~F} 1 \mathrm{r}$ reciprocal hybrids). The main objectives of my study were to investigate heterosis over both mid-parents and better parent and to determine combining abilities. In addition, to utilize the seven varieties in the production of F1 hybrids (F1 and F1r) to gain benefit from hybrid vigor phenomena In the same time, to estimate heritability in both broad and narrow senses of these studied traits in squash. Using fingerprints which were obtained through protein electrophoresis technique and RAPD-PCR technique for characterization and construction of genetic linkage maps and the molecular genetic diversity of parents support the use of marker-assisted selection (MAS) in squash cultivars breeding programs. Finally, to determine the important genetic parameters helping vegetable breeders to start a useful squash breeding programs. Now my work is evaluate these hybrids in many deferent conditions in my country Egypt to select those hybrids which showed high performances and exhibit good traits and high stability.
Volume 3 Issue I - 2016

Mohamed Abd Elhameid Abdein
Department of of Biology, Genetics and Plant Breeder at
Vegetable Breeding, Horticultural Research Institute, Egypt

Correspondence: Mohamed Abd Elhameid Abdein, Lecturer of Biology, Genetics and Plant Breeder at Vegetable Breeding Department, Horticultural Research Institute, ARC, Giza, Egypt, Tel 9665669078I8, Email abdeingene@yahoo.com

Received: January 19, 2016 | Published: January 29, 2016

\section{Survey the flora of cucurbitaceae}

I hope to find the all germplasm of some Cucurbitaceae in Egypt, this work by research about the wild plants and recording the data about it. The life seeds of some wild Cucurbitaceae I have from it and make self-pollinated to it to many successfully generations to stability and make to it fingerprint. After that I use it in program of breeding to produce a new hybrid and evaluated them at different seasons and locations in many conditions in Egypt.

\section{Future study about squash}

I want to use the technic tissue culture on squash to produce many numbers commercial of similar and topical plants on the new hybrids have a hybrid vigor, earliness traits, high yielding, disease resistance and environmental stress. Finally, in my experiments I want to make a mix by use the classic science of quantitative genetics and new science of tissue culture and molecular markers to improve the yield and qualities of vegetables crops especially squash and Plant breeding for disease resistance and environmental stress.

\section{Biography}

Mohamed Abd Elhameid Abdein, a Lecturer of Biology, Genetics and squash breeder. His main areas of research interest are plant breeding, molecular markers; survey the flora of Cucurbitaceae and environmental stress about the family of Cucurbitaceae. In addition to, his current research interests include the use of quantitative genetics, tissue culture and molecular markers to improve the yield and qualities of vegetable crops and Plant breeding for disease resistance and environmental stress.

\section{Acknowledgements}

None.

\section{Conflict of interest}

The author declares no conflict of interest. 